\title{
Negotiating the Maastricht Treaty
}

\section{Wilfried LOTH}

"Maastricht" means the end of a major struggle on the monetary union which had started at the Hague summit in December 1969 and which had been intensified since 1984 by French pressure against German reluctance. The French had several reasons to urge that such a union should be achieved: first, they saw it as a necessary element of a policy of economic growth on the European level; second, they strove for independence from the erratic movements of the dollar and the US policy of interest; third they aimed at destroying the hegemonic position of the German Bundesbank. German resistance resulted from the long-term fear of an "inflation union" and the institutional self-interest of the Bundesbank whose directors saw no reason to abandon their comfortable position. At the same time, Maastricht was the provisional end of an even much longer debate on a Political Union, the question of a Common Foreign and Security Policy and the institutional design of a united Europe. This debate had started with Charles de Gaulle's proposal for a Political Union in September 1960 and had led to many crises, sharp confrontations and tough struggles.

It is a commonplace to state that agreement on these crucial issues was reached due to the unexpected and sudden re-unification of Germany in 1990. Confronted with the danger of the end of the European Community, Helmut Kohl and François Mitterrand were able to find compromises on all the long-standing open questions; and these compromises set the basis for the institutional reforms of the Maastricht Treaty, the establishment of the monetary union, and the development of a Common Foreign and Security Policy. However, it is not very well known how these compromises were reached in detail and why the Maastricht Treaty obtained that specific complicated form which was disputed later on. By answering these questions, this article may contribute to a more qualified assessment of the Treaty, its merits and its shortcomings. ${ }^{1}$

\section{Agreement on a Monetary Union Conference}

The monetary union as the core element of the Maastricht Treaty had been on the European policy agenda since April 1989 when the so-called "Delors Committee" delivered its report. As agreed upon at the European Council meeting in Hannover on 27 and 28 June 1988, this body, consisting of all twelve central bank presidents

1. A wealth of information on the negotiation process can be found in K. DYSON, K. FEATHERSTONE, The Road to Maastricht. Negotiating Economic and Monetary Union, Oxford University Press, Oxford, 1999. This article is furthermore based on evidence from the French Presidential archives, the German Federal Chancellor Office, and contemporary public sources. 
of the European Community along with some further experts and acting under the chairmanship of Commission President Jacques Delors, had developed a roadmap for the achievement of a monetary union. It adhered to the German input by describing the goal of an independent European Central Bank system, led by the directorate of the European Central Bank as well as the presidents of the national banks and committed to the goal of price stability. In this, Mitterrand had given the French Committee member Jacques de Larosière his blessing, because he knew that the monetary union could not be achieved in any other way. In order to demonstrate the irrevocability of the setting of the exchange rates, it was necessary to introduce also a nominal Community currency. In contrast, when it came to the parallel development of a common economic and fiscal policy, which Delors regarded as indispensable if the monetary union were to function over the long term, there was only vague talk of "macro-economic coordination, including binding rules in the budgetary field". Delors struck the explicit mention of "transfer of decision power" to the European level contained in an early draft, because he considered it as impossible to reach a consensus on this.

Regarding the roadmap, Delors succeeded in gaining approval for a three-stage plan as well as for the recommendation that right at the beginning of this process there be "a clear political commitment to the final stage". With regard to a timeframe it was only recommended that the first stage should begin no later than the startingpoint of the free movement of capital on 1 July 1990. Besides, there was no clear statement as to which conditions needed to be fulfilled in order to move from the first to the second stage or from the second to the third, nor were any kind of time points specified for these transitions. During the first stage, convergence was to be further promoted by economic development and economic policy; and all member states were to join the exchange-rate mechanism of the European Monetary System (EMS). Additionally, a treaty on economic and monetary union was to be worked out. After the ratification of this treaty, the second stage could be entered upon, during which the European Central Bank system was to organize the transition towards full monetary union for the third stage.

As to the organization of the transition towards the second stage, the report of the Delors Commission remained just as vague. German Bundesbank president Karl-Otto Pöhl successfully fended off Larosière's demand to establish a European Monetary Fund for this transition phase, just as the idea to create a parallel European currency that was to be legal tender alongside the national currencies. The report only retained the provision that the European Central Bank was to have the possibility of accumulating "a certain amount of reserves" and using them for intervening in the foreignexchange markets. The ranges of fluctuation among the national currencies were to be narrowed as far as circumstances and progress toward convergence allowed. Additionally, agreements on precise rules determining the size and financing of budget deficits were to be reached; these were not yet to be binding, however. "Guidelines" for macro-economic development were to be passed by majority vote; at the same 
time, the "ultimate responsibility" for political decisions in this phase was still lying with the member states. ${ }^{2}$

It is true that the Bundesbank thereby retained the fundamental essentials regarding the shape of the future monetary union and that the pace of its realization remained unclear. Nevertheless, the recommendation for an immediate launch altogether with a simultaneous commitment to the final goal gave a strong impetus for a further development of the monetary system into a monetary union. This posed a serious dilemma for Federal Chancellor Helmut Kohl: on the one hand, he shared the analysis of the advocates of the monetary union like Delors and German Foreign Minister Hans-Dietrich Genscher; on the other hand, he had to act with particular caution precisely at the same time with regard to domestic politics. The criticism of his leadership had escalated, and his own general secretary, Heiner Geissler, was about to have him removed. Kohl therefore simply could not afford to deceive Finance Minister Theo Waigel, who had succeeded Franz-Josef Strauss as chairman of the Bavarian CSU and who was supporting the Chancellor against criticism within the party. In cabinet discussions, Genscher succeeded in winning approval for having the government support the Delors Report as well as for the start of the first stage on 1 July 1990. However, Waigel and his Secretary of State Hans Tietmeyer - whose expertise was greatly valued by the new Finance Minister - argued that before fixing a time for the beginning of the government conference, a whole series of "technical issues" had to be resolved. Kohl did not dare to contradict them. ${ }^{3}$

In Madrid, where the heads of state and of government gathered on 26 and 27 June, it was thus not possible to take further decisions. Kohl took advantage of Margaret Thatcher's opposition to negotiate a new treaty and presented himself as a mediator, trying so to play for time: : The report of the Delors Commission was hailed as an indispensable basis for preparing the monetary union, the first stage being scheduled to start on 1 July 1990. The government conference should only meet once the responsible bodies - that is the General Council, the Council of Finance Ministers, the Commission, the Committee of the Central Bank Governors and the Monetary Committee - had completed the necessary preparations. Under no circumstance should the government conference meet before the beginning of the first stage. Additionally, the Council explicitly approved the West German proposal to set unambiguous convergence criteria and also rejected the French plan for a European Reserve Fund. ${ }^{4}$

2. Bericht zur Wirtschafts- und Währungsunion der EG, in: Europa-Archiv, 44(1989), pp.D 283-304; H. KRÄGENAU, W. WETTER, Europäische Währungsunion. Vom Werner-Plan zum Vertrag von Maastricht. Analysen und Dokumentation, Nomos, Baden-Baden, 1993, pp.33-40. On the negotiations in the Delors Committee, see K. DYSON, K. FEATHERSTONE, op.cit., pp.342-350 and 713-720; additional material in J. DELORS, Erinnerungen eines Europäers, Parthas, Berlin, 2004, pp.385-389.

3. K. DYSON, K. FEATHERSTONE, op.cit., pp.350-354. On Kohl's domestic problems see also H.P. SCHWARZ, Helmut Kohl. Eine politische Biographie, Deutsche Verlags-Anstalt, Munich, 2012, pp.520-527.

4. Europa-Archiv, 44(1989), pp.D $406 \mathrm{ff}$. 
Mitterrand then sought to make use of his European Council presidency to give decisive impetus to the preparations for a government conference on monetary union and to wring a binding date for this meeting from the Germans. It should thus begin no later than before the end of 1990. The necessary decisions should be taken at the next Council meeting in December in Strasbourg; these were to be prepared by a working group composed of representatives of the Ministries of Finance and of Foreign Affairs under the leadership of Mitterrand's European advisor, Elisabeth Guigou. As Mitterrand told Thatcher during a lightning visit on 4 September, his intention was "to set the train on the rails"; and it should not be impeded by "one or two states". ${ }^{5}$ In other words, France was prepared to make a move on the monetary union even if Britain would not immediately join in.

Kohl agreed with Mitterrand's timeframe "in principle". However, his consent to Mitterrand's initiatives, as usually, was subjected to some conditions. Considering the upheavals in Hungary and Poland as well as the visible collapse of the SED regime in East Germany, the Chancellor was convinced that along with the economic and monetary integration, also the political unification of Europe had to be accelerated. This seemed necessary to him, firstly, in order to create a strong framework for the process of German reunification; secondly, he also saw new tasks emerging for the Community in order to overcome the legacies of Communism in Eastern Europe. On 24 October, Kohl went to Paris for a meeting with Mitterrand on this topic. As Mitterrand's adviser Jacques Attali noted during a dinner shared by the two leaders, "it would be necessary to tackle after the economic also a political European project". The chancellor also made it clear that in his view, such an initiative was urgent: "The summit in Strasbourg must send a clear message to the East".

Mitterrand didn't fail to notice that his guest reacted evasively to his question about fixing a date for the beginning of the government conference: "One can't decide anything before seeing what happens in Strasbourg". This made the French president mistrustful. Attali concluded his notes on this "head-spinning" meeting with the observation that "I feel for the first time that the Chancellor does not disclose everything he knows and he wants". 6 This mistrust developed into great anxiety when Kohl specified his ideas in a letter to Mitterrand on 27 November: in Strasbourg, the Finance Ministers and central bank presidents should be commissioned to prepare the government conference; and the conference should not only deal with the economic and monetary union but also, in a second phase, from the end of 1991 onward, with

5. AN [Archives nationales], 5AG4, 88 EG d.1, quoted in: J.-M. PALAYRET, La voie française vers l'Union économique et monétaire durant la négociation du traité de Maastricht (1988-1992), in: M. LIBERA, B. WASSENBERG (eds), L'Europe au cœur. Études pour Marie-Thérèse Bitsch, Peter Lang, Brussels, 2009, pp.197-221, here p.209.

6. J. ATTALI, Verbatim, tome 3: Chronique des années 1988-1991, Robert Laffont, Paris, 1995, pp. 325-327. On this and the following, also H.J. KÜSTERS, La controverse entre le Chancelier Helmut Kohl et le Président François Mitterrand à propos de la réforme institutionnelle de la Communauté européenne (1989/1990), in: M.-T. BITSCH (ed.), Le couple France-Allemagne et les institutions européennes, Bruylant, Bruxelles, 2001, pp.487-516, here pp.491-496; K. DYSON, K. FEATHERSTONE, op.cit., pp.363-366. 
other institutional reforms, especially with the strengthening of the position of the European Parliament. The "political decision on implementing a government conference on the economic and monetary union" should only be made in the middle of December 1990, and the negotiations should begin in early 1991. Both parts of the negotiations should be wrapped up over the course of 1992, "in December at the latest". As was emphasized in the conclusion of the document, the ratification could then take place promptly before the next elections to the European Parliament in May and June of $1994 .^{7}$

This announcement to postpone the political decision on the monetary union for another year, along with its incorporation into a more comprehensive reform project containing many pitfalls, was perceived in Paris as a covert rejection. "If that really is the position of the Chancellor", Attali commented, "then it means that he's been swayed by the British arguments. And that everything is buried. German problems will sweep across the European construction". "It was not only the project of the monetary union that threatened to fail at exactly the moment when it was, in the French view, especially urgent but also the incorporation of Germany altogether which was after all an essential motive not only for the French European policy.

The President then did his utmost to convince the Chancellor to offer binding approval for the summoning of a government conference on the monetary union at the upcoming Strasbourg Council meeting. An understanding on negotiations for a Political Union would surely be desirable in principle, but it should be deferred so as not to endanger the breakthrough on the monetary issue. During a phone call with Chancellor Kohl in the afternoon of 28 November, Mitterrand threatened that France only would approve Kohl's reunification plan if Bonn made three distinct commitments beforehand: the beginning of negotiations on the monetary union, the definitive recognition of Germany's border with Poland, and confirmation of the Federal Republic's renunciation of nuclear weapons. Mitterrand spoke still more darkly to Genscher, who had sought him out on 30 November in order to smooth the waves that Kohl's solo initiative had generated:

"If German unity is achieved before European unity, you'll have the Triple Alliance (France, Great Britain and the USSR) against you, exactly as in 1913 and 1939. [...] You'll be encircled, and that'll end in a war in which once again all Europeans will ally against the Germans. Is that what you want? Conversely, if German unity is achieved after there's been progress on the unity of Europe, then we'll help you".

No later than Kohl was reported this conversation, the Chancellor must have realized that his engagement for a Political Union was not sufficient to win France's support for the reunification process. This meant that he after all had to take a larger domestic policy risk if he wanted to retain the necessary room for manoeuvre as to the shaping

7. Kohl to Mitterrand, 27.11.1989, in: Deutsche Einheit. Sonderedition aus den Akten des Bundeskanzleramtes 1989/90, Oldenbourg, Munich, 1998, pp.565-567.

8. J. ATTALI, op.cit., pp.349.

9. Ibid., pp.320-323. On Genscher's visit, see also J. ATTALI, op.cit., pp.353 ff; H.-D. GENSCHER, Erinnerungen, Siedler, Berlin, 1995, pp.390 and 677-680. 
of the reunification process without at the same time endangering the European construct. Nor could he rule out the possible danger of losing the initiative to Genscher in the one question as well as the other, if the monetary union continued to be blocked. All this led him to give in on the issue of the monetary union. Shortly before the opening of the Council meeting on 8 December, the Chancellor's office let the Elysée know that Kohl was finally willing to fix a date for the opening of the government conference in December 1990. ${ }^{10}$

The Strasbourg Council meeting then began in a relatively relaxed atmosphere. As early as at the opening luncheon, Kohl declared that a clear roadmap was necessary "in order to demonstrate our will to achieve progress". As Council President, Mitterrand was able to confirm

"that the necessary majority exists for the summoning of a government conference in accordance with Article 236 of the Treaty. The government conference will meet before the end of 1990 at the invitation of the Italian government".

No decisions were made regarding the Political Union; it was only determined "that the economic and monetary union [was to] take fully into account the democratic requirement". The "Community Charter on Social Rights of Workers" was adopted against the vote of Margaret Thatcher, a move for which Mitterrand and Delors had long been fighting. Lastly, the Twelve also approved the establishment of the "European Bank for Reconstruction and Development". Mitterrand only had to concede to Thatcher that "the other OECD member states" - that is especially the US - would also be invited to participate. ${ }^{11}$

\section{Establishing a Political Union Conference}

Jacques Delors had been the first to articulate the need to hasten the European integration process in order to accelerate as well German unification, saying so internally and more or less clearly in public as well. Only three days after the fall of the Berlin Wall, he had declared on German television that according to the provisions of the Treaties of Rome, the way stood open for the citizens of the GDR to enter the European Community. In his inaugural address to the European Parliament at the beginning of his second term, he had argued "that the Community can only retain its attractiveness if it accelerates its integration". In his view, this included the idea "that

10. F. BOZO, Mitterrand, la fin de la guerre froide et l'unification allemande. De Yalta à Maastricht, Odile Jacob, Paris, 2005, p.152. On the following, ibid., pp.152-156; T. SCHABERT, Wie Weltgeschichte gemacht wird. Frankreich und die deutsche Einheit, Klett-Cotta, Stuttgart, 2002, pp. 425-428; U. LAPPENKÜPER, Mitterrand und Deutschland. Die enträtselte Sphinx, Oldenbourg, Munich, 2011, pp.269-271.

11. Schlussfolgerung des Vorsitzes der Straßburger Ratstagung, 08./09.12.1989, in: Jahrbuch der Europäischen Integration 1989/90, pp.421-438. 
comprehensive executive authority be transferred to the Commission" and as a consequence, there must be an "expansion of the powers of Parliament". ${ }^{12}$

Mitterrand's advisor on European issues Guigou, a one-time staffer of Delors during his time as Finance Minister, embraced the essentials of this argument in a memorandum to the President on 6 February of 1990. As she wrote, the Community needed to take an interest in "very quickly inventing an institutional armature that trivializes and restrains the German fact so that Germany determines its orientations within a Community framework and not autonomously". She therefore proposed to take up Kohl's initiative for the creation of a Political Union, a "European Union" overarching the existing institutions. Justifying the urgency of her proposal, she wrote that it would be better "to negotiate a European Union with a Germany that is for the time being still divided into two states and that needs the Community rather than with a reunited German that no longer needs anyone". ${ }^{13}$ In the run-up to the dinner on 15 February to which Mitterrand had invited Kohl, Guigou established contact with her West German counterpart Joachim Bitterlich and was able to reinforce her proposal with information on the Chancellor's willingness to undertake a joint initiative for the Political Union.

Mitterrand however hesitated to agree to the proposal about launching the Political Union. He still feared that differing views on the institutional configuration of the final political form of the Community could delay the implementation of the monetary union. On 15 February, his only concrete suggestion to Kohl was to bring forward the beginning of the government conference on monetary union, which was swiftly rejected by the Chancellor. Mitterrand gave his support to a joint Franco-German initiative for a Political Union only in late March as a result of a German proposal on this matter and after Kohl had pressurized Council President Charles Haughey into deciding on a government conference on Political Union at the upcoming special meeting of the heads of state and of government scheduled for 28 April. Meanwhile, the Belgian Prime Minister Wilfried Martens had brought more pressure to bear on Mitterrand by means of a memorandum - inspired by Delors - addressed to the partner governments - and calling for a government conference on institutional reforms.

The Franco-German initiative in the form of a joint letter from Mitterrand and Kohl to Council President Haughey on 18 April did not consider to take already a decision yet on the introduction of a further government conference at the upcoming Council meeting. Because Mitterrand feared a hasty commitment to Bonn's institutional conceptions, it was only possible for the time being to propose that the Foreign Ministers make preparations for a government conference on the Political Union. Only on the basis of their report a decision was to be made at the next regular Council meeting in late June. Regarding the timeframe for the government conference on Political Union, the joint letter suggested that it should occur parallel to the government conference on the monetary union so that "the totality of the relations among

12. Europa-Archiv, 45(1990), pp.D 269-282; J. DELORS, op.cit., pp.327-329.

13. AN, 5AG4, AH 35, Memorandum by Guigou, 06.02.1990, quoted in: F. BOZO, op.cit., pp.198f. On the following, ibid., pp.196-202 and 244-249. 
the member states can be transformed into a European Union by 1 January 1993". In terms of content, the proposal was relatively vague: the Political Union was to "strengthen the democratic legitimization of the Union" and "flesh out more efficiently" its institutions, but also provide for the "unity and coherence" of its activities "in the areas of economy, currency, and politics" as well as "defining and implementing a common foreign and defence policy". ${ }^{14}$

In Dublin, where the heads of state and of government met on 28 April, the FrancoGerman initiative, as expected, met with opposition by Thatcher. In the view of the British Prime Minister, German unification provided no argument for the deepening of the European Community - on the contrary, there was reason to block such a deepening: "The European construct will not bind Germany; it's rather the case that Germany will dominate the European construct", as she put it at a dinner at the French embassy in London in mid-March. ${ }^{15}$ As a consequence, it could only be decided in Dublin that before the next Council meeting on 25-26 June, the Foreign Ministers were to review the necessity of possible treaty amendments for strengthening democratic legitimacy and for effectively responding to the "challenges of the new situation". It was left open as to whether the summoning of a second parallel government conference would then actually be decided on. The European Council only stipulated that the treaty amendments necessary for the transition towards the second stage of the monetary union had to be in force by 1 January $1993 .{ }^{16}$ For Kohl, this did not represent the strong signal for progress on political unification that he regarded as necessary in order to secure the monetary union with the German electorate.

The Foreign Ministers of the Twelve nevertheless succeeded in agreeing on numerous principles in favour of the Political Union during a meeting on 19 and 20 May. Kohl and Genscher had reduced their conceptions of an institutional strengthening of the Community to a realistic level, so that unity could be more or less achieved on the idea that the European Council would continue to constitute the central institution of the Union; above this, the Community area and the area of political cooperation were to be more strongly interlinked. On the other hand, Roland Dumas, the French Minister, accommodated the reservations of various partners regarding a common foreign and defence policy to the effect that these were initially to be developed incrementally. On this basis, at the regular Council meeting also held in Dublin on 25 and 26 June, it was possible to reach the agreement that, parallel to the government conference on the monetary union, also a government conference on the Political Union was to be held. More specifically: the monetary conference was to begin on 13 December 1990 and the "political" one on 14 December. Both conferences were to complete their work so that the resulting treaties or treaty amendments could be ratified before the end of $1992 .{ }^{17}$

14. Europa-Archiv, 45(1990), p.D 283.

15. Embassy report, 13.03.1990, quoted in: F. BOZO, op.cit., p. 242.

16. Europa-Archiv, 45(1990), pp.D 284-288.

17. Jahrbuch der Europäischen Integration 1990/91, pp.417-420. 


\section{Negotiations on Political Union}

While preparing the second government conference, Kohl and Mitterrand continued to work closely together, to a certain extent for different motives: for Kohl and the West German government, it was primarily a matter of reducing the democratic deficit of the Community that had emerged after the development of Community activities in many new policy areas through the Single European Act; addressing that issue would secure the European orientation of German policy over the long term. The German public's fatigue regarding Europe, evident in several respects including the lower turnout elections to the European Parliament in June 1989, was definitely perceived in Bonn as an alarm signal. For their part, Mitterrand and his advisors were primarily aiming at strengthening the common foreign and defence policy. They fully expected that after the end of the Cold War, the American presence in Europe would diminish sooner or later; the French wanted to make use of this opportunity to achieve substantial progress in promoting European autonomy in world politics.

Both governments however agreed that the completion of the monetary union had to be accompanied by a strengthening of the political structures of the Community if the integration of the now sovereign Germans was to succeed over the long term. On the day after German unification had come into effect, Kohl sent a letter to the French President in which he expressed gratitude for Mitterrand's support and pledged his efforts to accelerate European unification. In a conversation with Attali, Mitterrand appeared propitiated and was at the same time resolved to seize the opportunity to strengthen the European Union, something which together with Kohl seemed feasible to him:

"The chancellor is sincere. And he will do all that if he has the time. That's a man of very great worth. But after him? One must integrate Germany into the Political Union, dissolve it in it, before Kohl leaves. If not, German arrogance - this time Bavarian rather than Prussian - will once again threaten peace in Europe". ${ }^{18}$

Both statesmen were at pains to demonstrate publicly that their divergences on the question of German unification policy - which had not passed completely unnoticed by the public - had by no means diminished their resolution to bring forward European unification.

Taking up a suggestion that Roland Dumas had made to his German counterpart Hans-Dietrich Genscher at the Franco-German summit of 17 and 18 September 1990 in Munich, both sides worked on another joint declaration that was to be presented by Kohl and Mitterrand in the run-up to the opening of both government conferences. In a joint letter of 6 December to the Council President (now Giulio Andreotti), Kohl committed himself more explicitly to the goal of a "common defence" than in the summer of 1987 when a joint Franco-German defence concept had to be developed. For this purpose, a "clear organic tie" between the Political Union and the WEU was to be created; in the long term, the WEU was to become a component of the Political

18. Note, 04.10.1990, in: J. ATTALI, op.cit., p.606. 
Union and consequently was also to include those Union members that did not yet belong to it up to that moment. The document listed as areas in which a "genuine common foreign policy" could develop, relations with the former Eastern Bloc countries and the states bordering the Mediterranean, disarmament talks, as well as development policy. Decisions would be made "fundamentally unanimously", but it would also be possible to allow for majority decision-making, especially involving modalities of policy implementation.

Paris acceded to Bonn's demands regarding the incorporation of immigration policy and the battle against international crime into the Community. It was in these areas that after the fall of the "Iron Curtain" and the re-emergence of ethnic conflicts in the former Eastern Bloc countries, Bonn was confronted with problems that it did not want to face and could not tackle alone. Therefore, the joint letter also urged the creation of a Justice and Home Affairs Council. Regarding the strengthening of the organs of the Community, Paris and Bonn agreed on giving the European Parliament a power of "co-decision" for legislative acts "in the narrower sense", which ultimately opened up the possibility of a veto right; also the President of the Commission and the Commission as a whole had to be approved by a majority of Parliament members and majority voting was introduced as a rule in the Council of Ministers. Additionally, in order to strengthen the democratic legitimacy of the Community, a "genuine European citizenship" should be created. ${ }^{19}$

Delors, however, considered this as insufficient to actually secure the Community's legitimacy and ability to act. At the intergovernmental conference in February 1991, making use of elaborations by his deputy cabinet chief, François Lamoureux, he presented a series of draft texts that went in the direction of more supra-nationality. According to these, actions in the foreign-policy realm were always to be submitted for approval if required by the Council President, the Commission, or a group of more than six member states. The decision to become active in a certain field was still to be taken unanimously by the European Council. Regarding the nature of the measures to be taken, the Council of Ministers should have to decide by qualified majority; their execution should primarily lie in the hands of the Commission. ${ }^{20}$ In general, the Commission was to receive greater freedom of action in issuing provisions for implementation. The Commission was also to assume the representation of the Community in international organizations such as the International Monetary Fund. Last-

19. Europa-Archiv, 46(1991), pp.D 25-27. On the course of the government conference on the Political Union, J. CLOOS, G. REINSCH, D. VIGNES, J. WEYLAND, Le traité de Maastricht. Genèse, analyse, commentaires, Bruylant, Brussels, 1994, pp.73-93; K. ENDO, The Presidency of the European Commission under Jacques Delors. The Politics of Shared Leadership, MacMillan, Houndsmills/New York, 1999, pp.170-190; D. ROMETSCH, Die Rolle und Funktionsweise der Europäischen Kommission in der Ära Delors, Peter Lang, Frankfurt/Main, 1999, pp.181-195; H. STARK, Kohl, l'Allemagne et l'Europe. La politique d'intégration européenne de la République fédérale 1982-1998, L'Harmattan, Paris, 2004, pp.179-213; F. BOZO, op.cit., pp.303-325. In the view of a participant, J. DELORS, op.cit., pp.403-411.

20. Commission Proposals on Common External Policy, in: Agence Europe, Documents, Nr. 1697/1698, 07.03.1991. 
ly, the Commission proposed that the Community be given the right to impose taxes of its own.

This went well beyond any consensus that could possibly be reached among the twelve governments; it also ran counter to Mitterrand's antipathy towards an increase in the Commission's power that he had repeatedly expressed. Government representatives at the working level showed little inclination to adopt the Commission's proposal. "We simply set aside the Commission's drafts and proceeded with others", as one member of the Council Secretariat remembered. ${ }^{21}$ In the middle of April, the Luxemburg Council presidency submitted a first draft treaty. This document took up the principle of different "pillars" of the future Union. This had been brought up for discussion by the French representative Pierre de Boissieu in order to counter the Commission's claims to power. In accordance with this concept, foreign and defence policy as well as justice and home policy would each constitute a distinct pillar of the Union, within which proceedings were to be strictly intergovernmental. In the Community area, the right of initiative of the Commission was to lose some of its significance because it was also to be conferred to the European Parliament. The Council should be able to alter Commission proposals by simple majority. In case of a difference of opinion between Council and Parliament, the Commission was no longer to have authority to make amendment proposals or simply withdraw the bill. ${ }^{22}$

Delors attacked, to a certain extent successfully, this draft as an attempt to reduce the Commission to a kind of secretariat that would be subordinate to the other institutions of the Community: at an informal Council of Ministers gathering hosted by Genscher in Dresden on 2 and 3 June 1991, Dutch Foreign Minister Hans van den Broek and his Belgian colleague Mark Eyskens severely criticized the proposed pillar structure. Genscher and the Italian Foreign Minister Gianni De Michelis, along with their counterparts from Spain, Ireland, and even Greece also voiced criticism. This convinced the Luxembourg Council presidency of the need to revise the draft treaty. In the version presented at the Luxembourg Council meeting on 28 and 29 June, the homogeneity of the institutional framework of the Union was more strongly emphasized. ${ }^{23}$

Nevertheless, the pillar structure was retained in the draft, and the Commission would thereby be prevented from having access to the fields of foreign policy and domestic security. The Dutch Council presidency of the second half of 1991 sought to change this once again by advocating its own draft treaty, which bound the three pillars together under Community law and further strengthened the rights of Parliament. Given that the Dutch draft also downplayed the role of the common foreign and defence policy, it failed to find support among many who advocated a strengthening of the Community organs. ${ }^{24}$ In late September, Bonn decided - heeding pres-

21. Interview with K. ENDO, op.cit., p.178.

22. Non-Paper of the Luxembourg Presidency, 15.04.1991, in: Agence Europe, Documents, Nr. 1709/1710, 03.05.1991.

23. Draft treaty, 18.06.1991, ibid., Nr. 1722/1723, 05.07.1991.

24. Draft treaty, 23.09.1991, ibid., Nr. 1733/1734, 03.10.1991. 
sure from Paris - to support the retention of the Luxembourg draft. The decision was taken at the session of the Council of Ministers of 30 September, the so-called "Black Monday" of the Dutch presidency.

The only thing Delors achieved was to have withdrawn the limitations of authority of the Commission contained in the Luxembourg draft. During a conclave of government representatives at Noordwijk in the Netherlands on 12 and 13 November, it was decided that legislative initiatives of Parliament were first to be presented to the Commission. This meant that the Commission's monopoly on initiatives was preserved, at least in the sense of having a veto right. Also, the Commission was still to be in a position to withdraw bills if did not agree with the changes made by other organs. The strengthening of the position of Parliament was essentially limited to the introduction of a co-decision-making process in individual areas and the expansion of oversight rights; also, the Commission would henceforth need to be confirmed by a parliamentary majority. For the Council of Ministers, majority voting was introduced as a rule, but there was to be a group of exceptions, such as when defining research framework programs and industrial policy.

Bonn's decision against the Dutch treaty draft represented at the same time a statement in favour of an autonomous European defence system, which had been opposed not only by the Dutch government, but also by the British, Danish and Portuguese governments. They argued that the already-threatened cohesion of NATO ought not to be further endangered by emphasizing a European defence identity. The formulation of the Franco-German programme, which Dumas and Genscher had presented on 4 February ${ }^{25}$ did therefore not find a common consent. At the Luxembourg Council Meeting, the only agreement reached was to postpone the decision on this programme until the closing phase of the government conference. In Paris, doubts began to arise as to whether Bonn was actually willing to involve itself in an independent defence; in the main question of the day concerning common foreign policy - the position toward the Serbian intervention against the declarations of independence by Slovenia and Croatia in late June - the two partners took opposing sides. Mitterrand was once again worried about the stability of borders in Europe, whereas the German government was under pressure from South German sympathizers of the former Habsburg territories.

In order to banish the risk that the Franco-German initiative for a common foreign and defence policy would fail, Kohl, at a meeting in Lille on 25 June suggested to Mitterrand that there be another joint foray. This resulted, by the beginning of October, in a new joint letter addressed to the Council chairman, for the time being Dutch Prime Minister Ruud Lubbers. The document specified the goal of foreign and defence policy in three points. Firstly, a draft text of treaty terms on these matters was offered, naming the WEU as the organ charged with carrying out common foreign policy but at the same time declaring that the "specifics of the defence policy of individual member states" were "unaffected". A review of these terms was announced

25. Der Bundesminister des Auswärtigen informiert. Mitteilung für die Presse (German Foreign Minister Press Release), 06.02.1991. 
for no later than 1996. Secondly, Bonn and Paris presented a draft declaration of WEU member states, which was to be appended to the Union treaty; this emphasized the "incremental expansion of the WEU into the defence component of the Union" as well as the goal of "creating a European pillar" of the Atlantic alliance. Thirdly, the Chancellor and the President announced not only an expansion of Franco-German military units, but also declared that these could "constitute the nucleus of a European corps" in which "forces of other members of the WEU" participated. ${ }^{26}$

Thatcher's successor John Major declared to Mitterrand that a subordination of the WEU to the guidelines of the Union would be absolutely out of the question. However, in a declaration of the NATO Council on 8 November, the US government had accepted the "development of a defence identity for Europe". Thus, at the Council meeting of 9 and 10 December in Maastricht, at the conclusion of treaty negotiations, the British Prime Minister had to content himself with demanding to tone down the formulations of the Franco-German draft. The treaty text now contained only the statement that the common defence policy "could in due course lead to a common defence"; for practical measures following from Council decisions on defence policy, there was an assumption of "accord" between the Council and the organs of the WEU. Additionally, absolutely no majority decision-making was permitted on "questions touching the field of defence-policy". ${ }^{27}$ Through close cooperation, Mitterrand and Kohl were able to prevent any further watering down of the defence perspectives during the Council meeting in Maastricht. ${ }^{28}$

\section{Negotiations on Monetary Union}

As to the timeframe fixed for the monetary union, Mitterrand and Delors voted in agreement for precise political determinations. The second stage of the monetary union was to begin as soon as possible, that is, upon the entry into force of the treaties on 1 January 1993. Conveniently, this was also the date on which the internal market was to be completed. Theo Waigel and new State Secretary Horst Köhler now at the head of the German Finance Ministry, were averse to fixing a date and instead wanted the achievement of objective criteria such as price stability and budgetary discipline. Finally, at a Council meeting in Rome on 28 and 29 October 1990, Kohl was ready for a compromise: the second stage was to begin on 1 January 1994, at least if "sufficient" progress in real-economic and monetary convergence had been achieved by then - a vague formulation that no longer left much manoeuvring room for the

26. Letter of 14.10.1991, Europa-Archiv, 46(1991), pp.D 571-574.

27. EU Treaty, Art.J.4.

28. On the course of the meeting, P. FAVIER, M. MARTIN-ROLLAND, La décennie Mitterrand, vol. 4, Les déchirements, 1991-1995, Eds du Seuil, Paris, 1999, pp.227 f. 
German neo-liberals to delay the actual beginning of the monetary union any further. ${ }^{29}$

Kohl however did not yet give in to pressure from Mitterrand to fix a date for the transition towards the third stage, the introduction of the Community currency. Only when in March 1991 Genscher publicly pleaded for 1 January 1997 as the transition date did Kohl acknowledge the need for a clear timeline. Yet, in order to avoid criticism from those who had a sentimental attachment to the German mark, he still did not want to name a precise concrete date. It was Andreotti at the Maastricht Council meeting who first brought 1 January 1999 into play as the latest date for the beginning of the currency union, and this was accepted. If before the end of 1996 the Council was to determine by qualified majority that a majority of member states had fulfilled the criteria for joining, the monetary union could then begin on 1 January 1997. Otherwise, a decision was to be taken before 1 July 1998 on which states could participate.

Pressure was thus put on the economically-weaker countries to make serious efforts to meet the entry criteria: New debt not over three percent, total debt not over sixty percent of GNP, an inflation rate not over 1.5 percent of the average of the rates in the three most stable states, long-term interest rates not over two percent more than in those states, and no devaluation within the EMS over the previous two years. At the same time, however, there developed a certain amount of manoeuvring room for a generous interpretation of these criteria, in case that in 1998 a country such as France still would clearly diverge from the level of the Federal Republic. Waigel and Köhler who were completely surprised by Kohl's decision to agree on a fixed date ${ }^{30}$ had to accept that the Chancellor preferred the irreversibility of the decision to a complete guarantee of stability.

Great Britain was granted the possibility, even with a positive assessment of its economic performance, of foregoing participation in the third stage. This was the price that had to be paid in order to avoid having British Prime Minister John Major use his veto to block the necessary treaty amendments. At the same time, this settlement still kept open a path for British participation. Such a decision - fundamentally desired by all partners - could not in fact be excluded from the realm of possibility after the up-coming 1992 parliamentary elections. Earlier, while serving as Chancellor of the Exchequer, Major, along with Foreign Minister Douglas Hurd, had forced through Britain's entry into the EMS on 5 October 1990; then, widespread criticism of Thatcher's aggressively anti-Europe rhetoric had six weeks later even led to the Prime Minister's fall. There was not necessarily an underlying intention to participate in the Community currency, but Thatcher's opponents hoped that the problems of the British economy, such as rising inflation and a massive balance of trade deficit, could be better brought under control if the country participated in the European Monetary System. They were also convinced that, as a member, they could

29. K. DYSON, K. FEATHERSTONE, op.cit., pp.395-399; on the following, ibid., pp.202-255, 370-45, and 726-740.

30. See the witness of Hans Tietmeyer in: H.-P. SCHWARZ, op.cit., p.701. 
more easily bring their influence to bear on its construction than by remaining on the sidelines. Britain should take its place "at the very heart of Europe", as the new Prime Minister John Major proclaimed during his first public appearance in Bonn. ${ }^{31}$

The Dutch government proposed that all member states have the option of quitting the monetary union after the point when the Council decided on the transition towards the third stage; this proposition however was rejected at an informal meeting of the Finance Ministers on 1 December 1991 in Scheveningen in the Netherlands. Then, the Danish government demanded a special right to withdraw, advancing the provisions of the country's constitution: the Danish government asserted that entry into the monetary union might well require approval by a national referendum and for that reason it could not commit itself definitively in a treaty at that juncture. The partners did agree to this demand by providing an additional protocol, knowing that much less was at stake here than in the British case, considering the weight of the Community currency in the world currency structure and the cohesion of the internal market.

This compromise character of the monetary union agreements revealed itself still more clearly at the moment, when the decisions on the second stage were to be taken. Köhler, who carried on the negotiations for the German side with backing from Waigel and Kohl, had to accept that the preparations for the third stage were not simply left to the Committee of National Bank Governors but would be taken up by a "European Monetary Institute" under the leadership of an external president chosen by the European Council. This monetary institute would however not take over the coordination of national monetary policies at that time, as France - represented by Treasury Director Jean-Claude Trichet - and the Commission were demanding for a European Central Bank that would be created at the beginning of the second stage. Likewise, this institute was not to take on responsibility for currency reserves at that time. National central banks could transfer currency reserves to the institute, which would then act only under their mandate.

Regarding the already-accepted independence of the European Central Bank system and the commitment to the goal of currency stability, the German side had to accept that the independence of the national central banks would be realized before the beginning of the third rather than the second stage. On the other hand, French Economy Minister Pierre Bérégovoy's hopes that a comprehensive "economic government" of the Community would necessarily go together with the creation of the Community currency waned as, instead of binding "guidelines", the Council would only be able to issue a "recommendation"; whereas financial support for member states in difficulties would depend on the unanimous vote of the Council. As the Bundesbank had demanded, there was an explicit ban on holding the Community liable for the debts of individual member states; states with an "excessive government deficit" risked "fines of an appropriate size". At the closing ministerial

31. Speech, 11.03.1991, quoted in: H. YOUNG, This Blessed Plot. Britain and Europe from Churchill to Blair, Macmillan, London, 1998, p.374. Cf. ibid., pp.362-374; K. DYSON, K. FEATHERSTONE, op.cit., pp.644-682; and A. FOSTER, Britain and the Maastricht negotiations, St. Martin's Press, New York, 1999. 
meeting in Brussels on 2 and 3 December, Waigel and Köhler obtained, that a decision was made to the effect that, regarding the exchange-rate policy, the Council, instead of guidelines, could only provide "general orientations". Additionally, it was determined that these orientations "shall be without prejudice to the primary objective of the ESCB to maintain price stability". 32

Waigel and Köhler were also successful in fending off the Spanish demand to establish a "convergence fund" in order to assist weaker member states. Commitment to social and economic cohesion was inserted in a protocol attached to the EU Treaty. The latter announced the creation of a "Cohesion Fund" with which weaker member states could be supported on "projects in the areas of environment and trans-European networks". There was thus a narrow restriction on redistribution needed as part of the promotion of convergence. Likewise, determinations on the authority of the Community in the realm of social policy - securing minimal standards in promoting employment, working conditions, equality between the sexes and worker participation in management - were relegated to a separate agreement, which Great Britain did not sign. In Maastricht, Kohl was able to push through a decision that a further government conference in 1996 would review the practicability of the agreed-upon stipulations. This preserved the opportunity for all participants to make improvements in line with their views.

\section{Saving with Shortcomings}

The agreement in Maastricht can therefore be considered from two different points of view. On the one hand, Kohl and Mitterrand had succeeded - by means of significant effort - in preventing the European unification process from being compromised by German reunification and in addition had even made it advance further. A common currency brought about a degree of integration and European state-like structures that made it become irreversible. On the other hand, progress in areas especially important to either the German Chancellor or the French President didn't meet the requirements for achieving lasting success. Contributions to reduce the deficit of democracy by strengthening the rights of Parliament and expanding majority-voting in the Council of Ministers had to a great extent been offset by the proliferation of procedures. The commitment to the goal of common decision-making structures in the field of defence was relativized by mandating unanimity on the way to their realization.

These shortcomings, which prompted Delors to speak of an "organized schizophrenia", ${ }^{33}$ were to an extent due to the fact that, since the turn of the year

32. Articles 103, 104, and 109 (2) of the EC Treaty. For an overview of the decisions on the monetary union, see H. UNGER, A concise history of European monetary integration: From EPU to EMU, Quorum books, Westport/Connecticut, 1997, pp.229-242.

33. Speech to the European Parliament, 20.11.1991. 
1989-90, cooperation between Delors and Mitterrand had given way to prickly tension. Due to an obviously exaggerated self-regard, Delors had neglected to reach an agreement with Mitterrand on the institutional questions. For his part, the French President had given little thought to how the "economic government" and the common foreign and defence policy were to function. A coherent negotiating strategy for the expansion of the Community could not develop under such circumstances. The network build by Delors, Genscher and Dumas (with Guigou as decisive contact to Mitterrand) could not plainly work. Since the beginning of 1991 Delors had largely acted in isolation and could be glad in the end to have preserved the status quo for the Commission.

The deficits of an "economic governance" largely complained during the presentday "Euro-crisis" are mainly the result of the influence of the German Bundesbank insisting on the independence of a European Central Bank. Thus, attempts to stabilize the monetary union in the long run were - ironically enough - defeated by the German defenders of monetary stability themselves, by fear of involvement of such a government in monetary policies. It is hard to see how this influence of the Bundesbank could have been minimized. German reunification helped to find compromises and thus to speed up the establishment of the European monetary union, but the political considerations in the context of the reunification process could not push away all resistance against the ambitious monetary union project. Without German reunification, it is highly probable that the monetary union project would nevertheless have succeeded later on, but in a similar form.

Several weeks went by before the treaty on the founding of the European Community, which built on the revised EEC Treaty, as well as the Treaty on the European Union with all the protocols and declarations could be edited and translated into all official languages. On 7 February 1992, the Foreign and Finance Ministers of the Twelve assembled once again in Maastricht in order to sign the treaties. Three-anda-half months later, at the conclusion of the Franco-German summit in La Rochelle on 22 May 1992, the two governments announced the formation of the Franco-German corps, which would number approximately $35,000 \mathrm{men}$. At the Council meeting in Edinburgh on 11 and 12 December 1992, it was finally possible to make decisions about the seats of important Community organs: the official seat of the Commission, which in the meantime was employing more than seventeen thousand civil servants, was assigned to Brussels - shortly after the Berlaymont Building had to be vacated due to asbestos contamination. Parliament was to meet once per month in Strasbourg, while further plenary sessions and committee meetings as well as sessions of the Council of Ministers were to take place in Brussels. Thus, multiplicity of the arrangements made in Maastricht was also reflected in the inconsistency of its geographic location. 


\section{Demokratiestudien. Demokratie und Demokratisierung in Theorie und Empirie}

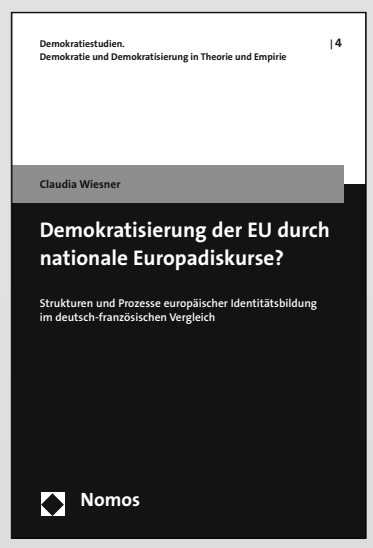

Demokratisierung der EU durch nationale Europadiskurse?

Strukturen und Prozesse europäischer Identitätsbildung im deutschfranzösischen Vergleich Von Claudia Wiesner 2013, Band 4, ca. 500 S., brosch., ca. 90,- $€$ ISBN 978-3-8487-0536-8

Erscheint ca. Juni 2013

www.nomos-shop.de/21043

Können nationale Europadiskurse europäische Identität erzeugen und damit zur Demokratisierung der EU beitragen? Aufbauend auf einer ausführlichen vergleichenden Untersuchung nationaler Europadiskurse sowie der politischen Systeme und Kulturen Deutschlands und Frankreichs liefert der Band zahlreiche Ergebnisse sowie weiterführende Hypothesen und Modelle zu dieser Frage.

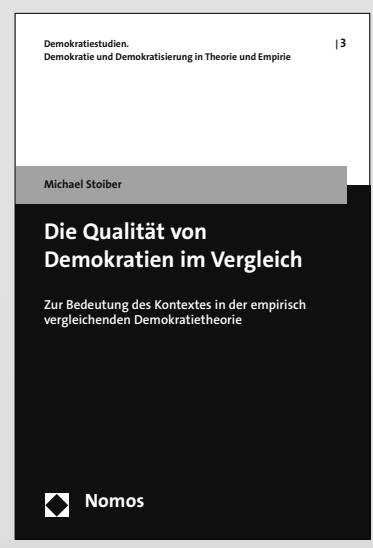

\section{Die Qualität von Demokratien im Vergleich}

Zur Bedeutung des Kontextes in der empirisch vergleichenden Demokratietheorie Von Michael Stoiber 2011, Band 3, 393 S., brosch., 64,- $€$ ISBN 978-3-8329-6244-9 www.nomos-shop.de/13221

Wie erfasst man die Varianz in der demokratischen Qualität von Demokratien? Auf der Basis des Kontextes kann für jedes Land eine optimale Beteiligungsstruktur ermittelt werden, die mit den realen Strukturen und deren Effektivität konfrontiert werden. Ein erster Pretest in zehn westlichen Demokratien zeigt die empirische Anwendbarkeit des Modells. 